Research Article

\title{
International Labor Migration: Employment, Costs and Income of Export Labors in Yen Khe Commune, Thanh Ba District, Phu Tho Province, Vietnam

\author{
Nguyen Tuong Huy ${ }^{1}$, Nguyen Thi Thu Thao ${ }^{2}$
}

${ }^{1}$ Faculty of Geography, Hanoi National University of Education, 136 Xuan Thuy, Cau Giay, Hanoi, Vietnam ${ }^{2}$ Yen Khe High School, Yen Khe, Thanh Ba, Phu Tho, Vietnam

Corresponding Author Email: tuonghuy@ hnue.edu.vn

\begin{abstract}
In the context of globalization and economic integration, labor mobility in general, international labor migration and export in particular are increasingly playing an important role in reshaping the future of the world's economic geography. This study is conducted to provide insights into employment, costs and incomes of export labors in Yen Khe, Thanh Ba district, Phu Tho province. In-depth interviews and questionnaire surveys were applied to collect primary data on employment, costs and incomes of export labors, related issues and consequences. These were also supplemented by the secondary data collected from different sources during the study process. The study found that labor export not only helps to create jobs, reduce unemployment and underemployment, but also to diversify jobs for workers, contributing to the restructure of the local economy. Remittances from export labors contribute directly to the increase of individual workers and their families' incomes, transforming the income structure in the way that is less dependent on local livelihood capitals and local livelihood strategies. However, labor export has also posed issues and consequences for export labors and their families. Notably, the status of illegal labor abroad, investment capital for labor export and related debt, services for labor export, voluntary unemployment, family conflicts, income inequality caused by remittances.
\end{abstract}

Keywords: labor migration, labor export, livelihood, poverty, Vietnam

\section{Introduction}

In the context of globalization and economic integration, labor migration in general, international labor migration and export in particular are increasingly playing an important role in reshaping the future of the world's economic geography. The study site, Yen Khe is a poor mountainous commune in Thanh $\mathrm{Ba}$ district, Phu Tho province, with natural conditions and resources mainly suitable for agricultural development. Given the limitations on livelihood capitals while having a large population, local employment is insufficient and does not guarantee income for a part of the labor force (People's Committee of Yen Khe Commune, 2015, 2017b). Therefore, labor export in particular is a livelihood strategy being selected by an increasing number of workers here. Labor export has created jobs for a significant number of rural workers. Remittances from abroad help increase household income and transform the economy structure in the way that is less dependent on local livelihood resources. As a result of labor export, many households have been able to invest in production, education and health care. The poverty rate has decreased significantly, the living standards of many households with export labor have clearly improved (Department of Labor - Invalids and Social Affairs of Thanh Ba District, 2018; People's Committee of Yen Khe Commune, 2015, 2017a, 2017b). However, labor export also raises many issues such as unemployment, income differentiation and other related consequences. Both positive and negative impacts of labor migration in Vietnam have been discussed elsewhere based mainly on the secondary data at national level (Anh, 2008; Consular Department of the Vietnamese Foreign Ministry, 2011; Duyen, 2009; Ishizuka, 2013).

This study provides insights into employment, costs and incomes of export workers in Yen Khe. The paper begins with an overview of the study site and the research methods applied to collect the data. The paper then analyzes employment changes and employment issues of workers before, during and after working overseas. The next sections provide an analysis on expenses for labor export and income from export labor; then it uncovers the issues and consequences related to the costs of and income from labor export.

\section{The study site and research methods}

Listed as a poor mountainous commune in Thanh Ba district, Phu Tho province Yen Khe has natural conditions and natural resources mainly suitable for agricultural development. Yen Khe has total population of 5,122 people, a high population density of 713 people/km2, and population growth rate of about $0.75 \%$ (data for 2017) (Thanh Ba District Statistical Office, 2010 - 2017). The total number of labors is 2,660, accounting for $53 \%$ of the population. In which nonagricultural labor accounted for $31.1 \%$, agricultural labor accounted for $68.9 \%$ of the total labor. Labor with primary education accounted for $1 \%$, secondary education accounted for $54 \%$, high school education or higher accounted for $45 \%$ (People's Committee of Yen Khe Commune, 2015, 2017b). Abundant labor force is considered as an important resource for economic development but it also puts high pressure on 
employment. Therefore, labor export is one of the important solutions to create jobs and improve living standards for local people. Regarding economic structure, agriculture accounts for a low proportion of $16 \%$ of the commune's production value, manufacturing - construction and handicraft is $22 \%$ and the services is $21 \%$. Income from other sources (pensions, remittances from abroad, remittances from migrant workers to other localities throughout the country) accounts for $41 \%$ (People's Committee of Yen Khe Commune, 2015, 2017b; Thanh Ba District Statistical Office, 2010 - 2017). Thus, labor export is considered as an option that plays an important role for socio-economic development, people in Yen Khe commune.

In the period from 2010 to 2017, Yen Khe had 250 labors working abroad as export labors, of which 21 cases came back and but continue to go abroad to work for the second time. The total number of export laborers for the period is 229 people from 221 households. On average, one out of every 7.7 households went to work overseas. Out of these 229 workers, 98 returned and are currently staying at the commune. The number of laborers currently working abroad is 131, accounting for $8.6 \%$ of total people at working age of the commune. The commune's export workers work in 11 countries and territories. In which there are 4 main markets are Taiwan (56.4\%), Malaysia (18.4\%), Japan (9.6\%) and South Korea (9.2\%). Other markets such as Arab, Russian Federation, Turkey, and Angola all account for a small proportion (People's Committee of Yen Khe Commune, 2017a).

Primary data were collected between November 2017 and November 2018. In-depth interviews were conducted with officials from district to commune and village level, with the bank officials, export workers and their relatives, representatives of households without export labor to obtain data on the study site's socio-economic geography, current status of labor export, and the influences of labor export on employment issues, costs and income from export labor. The collected primary data were supplemented by secondary data related to labor export collected during the fieldwork. The questionnaire surveys were conducted for 50 households, divided into 2 groups, 25 households with export labor and 25 households without export labor. These participants were recruited from all 15 villages in which each group was selected according to the income level, high income, average income and low income. The questionnaire explored the influences of labor export on employment issues, costs and income from export labor of households. The data obtained from the questionnaire surveys were triangulated with and enriched by informal interviews, observations and field records. Secondary data on international migration and labor export of Vietnam were also used during the implementation.

\section{Employment before, during and after labor export}

In the context of limitation of development resources and local livelihoods, employment is the first and urgent need for laborers in Yen Khe commune. Therefore, strengthening labor export is one of the important goals in the National Target Program on Employment and Vocational Training for the period 2012-2015 (Vietnam Prime Minister, 2012) and the Target Program for Vocational Education - Employment and Occupational Safety period 2016-2020 (Vietnam Prime Minister, 2017) with many policies to support labor export, especially for poor communes and districts.

Employment has been the first benefit that labor export brings to local labors. In the period of 2010 - 2017, there were 229 new jobs created for 229 workers of Yen Khe commune through labor export (People's Committee of Yen Khe Commune, 2017a). The specific jobs that employees do before, during and after labor export are vastly different. These jobs can be classified into three sectors, (i) agriculture (ii) manufacturing, construction and handicraft, and (iii) services. Employment details of workers before going abroad, overseas and after returning home are reflected in Table 1.

Table 1. Employment classified by economy sectors

\begin{tabular}{|c|c|c|c|}
\hline Sector & $\begin{array}{l}\text { Before going to } \\
\text { abroad }\end{array}$ & Overseas & After returning home \\
\hline Agriculture & $\begin{array}{l}\text { Crop production, } \\
\text { livestock, } \\
\text { fisheries }\end{array}$ & $\begin{array}{l}\text { Growing clean vegetables, flowers, } \\
\text { aquaculture }\end{array}$ & Crop production, livestock, and fisheries \\
\hline $\begin{array}{l}\text { Manufacturing, } \\
\text { construction and } \\
\text { handicraft }\end{array}$ & $\begin{array}{l}\text { Mechanic workers, } \\
\text { brick-makers, glass- } \\
\text { aluminum workers, } \\
\text { knitting }\end{array}$ & $\begin{array}{l}\text { Mechanical workers, electronics, } \\
\text { industrial gloves, industrial apparel, } \\
\text { plastic manufacturing, weaving, } \\
\text { woodworking, seafood processing, } \\
\text { coffee processing, frozen food, book } \\
\text { printing, driving, construction }\end{array}$ & $\begin{array}{l}\text { Mechanical workers, electronics, } \\
\text { sewing, carpenters }\end{array}$ \\
\hline Services & $\begin{array}{l}\text { Nurse, small traders, } \\
\text { Car repairman, } \\
\text { Self-employed }\end{array}$ & Maids, casino services, pet dogs & $\begin{array}{l}\text { Car garage management, cafe shops, } \\
\text { online sales, grocery, medicine, security, } \\
\text { maid, taxi driver, construction assistant, } \\
\text { labor export consultant, self-employed }\end{array}$ \\
\hline
\end{tabular}

Source: (People's Committee of Yen Khe Commune, 2017a) and Fieldwork from November 2017 to November 2018 
Nguyen T.H. and Nguyen, T.T.T. / International Labor Migration: Employment, Costs and Income of Export Labors in Yen Khe Commune, Thanh Ba District, Phu Tho Province, Vietnam

Local reports and survey results show that the employment structure of employees by economic sector has markedly changed before going abroad, overseas and after returning home (see Table 2).

Table 2. Employment structure by economic sectors

\begin{tabular}{|c|c|c|c|c|c|c|}
\hline \multirow[t]{2}{*}{ Sector } & \multicolumn{2}{|c|}{$\begin{array}{l}\text { Before going to } \\
\text { abroad }\end{array}$} & \multicolumn{2}{|c|}{ Overseas } & \multicolumn{2}{|c|}{$\begin{array}{l}\text { After returning } \\
\text { home }\end{array}$} \\
\hline & labor & $\%$ & labor & $\%$ & labor & $\%$ \\
\hline Agriculture & 194 & 85 & 4 & 2 & 42 & 43 \\
\hline $\begin{array}{llll}\text { Industry } & - & \text { construction } & \text { and } \\
\text { handicraft } & & \end{array}$ & 12 & 5 & 200 & 87 & 14 & 14 \\
\hline Service industries & 9 & 4 & 25 & 11 & 32 & 33 \\
\hline Unemployment & 14 & 6 & 0 & 0 & 10 & 10 \\
\hline Total & 229 & 100 & 229 & 100 & 98 & 100 \\
\hline
\end{tabular}

Source: (People's Committee of Yen Khe Commune, 2017a) and Fieldwork from November 2017 to November 2018

Before going abroad, laborers mainly worked in agriculture $(85 \%)$. The number of labors working in industry construction and small industry and service industries accounts for a small proportion, about $9 \%$. Remarkably, there is a part of unemployed labor, about $6 \%$.

During their time abroad, these workers mainly work in manufacturing and construction sector, accounting for $87 \%$ while the number of employees working in the remaining industries is not much, accounting for about $13 \%$. Vietnamese workers abroad mainly do common jobs that require more physical and ingenious. The survey results show that the workers in Yen Khe going abroad hold diverse educational background and professional qualifications. The lowest education level is grade 7 and the highest is university-level professionals. For those who graduated university, college or vocational education, the professions they have been trained in Vietnam are not suitable for the demand for high quality labor abroad. Therefore, when working abroad, they are considered as unskilled labor. Many export workers have to do manually hard work that not many local workers can do not or want to do. Interview results show that overseas jobs are considered suitable for the physical health condition of Vietnamese workers. All 25 workers interviewed said that the work load in 8 hours is moderate. They all desire to work overtime to increase their income. However, whether or not this demand is met depends on the contracts, the companies that they work, and the labor management abroad.

Illegal labor is also a big problem for Vietnamese workers abroad. Many workers have fled to work illegally outside during their contract time. Some stay to work illegally after their contracts expire. Illegal workers are not only at risk but also do not receive any legal protection and assistance when facing uncertainties and risks overseas. Of the 25 workers interviewed, three in Taiwan admitted that due to the small number of jobs at the company, they escaped to work illegally full-time or part-time. Among them, there is 1 worker who has not come back for 8 consecutive years while the labor contract is normally signed for every 3 years.

Box 1. Why the export laborers fled to work illegally?
No Vietnamese laborers would want to flee to work outside during the time they work overseas because this is very dangerous. Through police raids, some workers got an accident or even lost their lives on the run. If they are caught by the police, they are at risk of being beaten. Then within 2-3 days they will be deported back home immediately. If they confess to Taiwanese police, they will have 1 month to prepare to return home. Illegal laborers do not have the opportunity to return to labor export again. However, many workers still risked their lives to flee to work outside during the contract period and at the end of the labor contract. The reason is that the work in some companies is limited, no overtime work leading to low income. In some cases, work are not the same as the contracts signed with Vietnamese brokerage enterprises but very heavy. Moreover, every month, apart from the insurance, the companies have to deduct $5 \%-7 \%$ of our income for brokers' commission. Thus, the longer we work abroad, the more brokers will earn. While the work outside is dangerous, the salary is higher. For me, 8 years away from home, if I return home I will have to stay at home, I'll thus try to stay here to earn money for a while.

Interviewing Ms. B., an export labor in Taiwan

When returning home, with the money earned, the skills and professional improved, workers have found more diverse and appropriate jobs locally. However, the number of workers returning to work in agriculture sector is still high, accounting for about $43 \%$. Notably, the unemployment rate among the export workers after returning home is quite high, about $10 \%$. This reflects the difficulties and inadequacies in job creation/job availability for the export workers who return home. Out of 25 workers interviewed, up to 6 cases have signed the contract to work abroad for the second time, 13 workers have not returned. When asked about their planned work after returning home, 13 workers were very vague with no clear intention about what they were going to do after returning home. There are 20 out of 25 workers who want to 
continue to work overseas as export laborers for the second contract.

Interview results show that workers who are working abroad have no clear intention for their employment when returning home. Living and working abroad for a long time, they are familiar with a decent job, a civilized lifestyle, a higher standard of living in the country they worked. Therefore they are facing the fear of unemployment, unable to adapt to the working environment or unable to find suitable jobs in Vietnam.

\section{Box 2. Employment issues after returning home}

I have no specific plans for my work after returning home. Three years of working as export labor in Japan, I have learned a lot of knowledge, skills and working styles but I can only use Japanese to communicate in familiar social contexts. The skills I learned from working in Japan are also difficult to apply in Vietnam.

\section{Interviewing $M r$. T., an export labor in Japan}

Employment after returning home is still a difficult problem that the export labor faced after returning home. Ms. D (6 years in Malaysia, 35 years old, education level 9/12) could not get a job in industrial zones because of her senior age, and her professional qualifications could not meet the requirements of the job. Ms. H (6 years in Malaysia) spent all the money earned on building a house and buying cars, and then has returned to cultivating and animal raising work as before. $\mathrm{Mr}$. $\mathrm{H}$ returned home after 4 months of working in Taiwan due to weak health, unable to meet the requirements of the job. His family had to send money to him to buy a plane ticket to return home. Mr. $\mathrm{H}$ (23 years old, University of Physical Education and Sports, working in Malaysia) and Ms. A (24 years old, University of Education, working in Taiwan) wish to use the money earned from export labor to find a job in the public sector that is suitable to their professional skills

\section{Expenses for labor export}

Going to work overseas is considered as an important decision of the workers and their families. This decision is influenced by many different factors, but most importantly, it requires large economic investments (Black, Bennett, Thomas, \&
Beddington, 2011). To work abroad, households have to mobilize funds from different sources. According to our survey from 25 households with labor export, the investment sources for labor export are diverse, including savings from production activities of the family, loans from relatives, preferential loans for social policies of agricultural banks, savings of the workers them self or their relatives who worked abroad previously.

Interview results show that only 3 out of 25 households can afford to invest in labor export, 4 households re-use the income from their previous overseas working, which is a relatively safe source of capital because workers do not have to pay interests. Six households borrowed money from relatives and 14 households borrowed from the bank at different interest rates. Currently, the Social Policy Bank and the Bank for Agriculture and Rural Development apply preferential policies for people who want to take loans to invest in labor export. However, they will be under high pressure to repay the debt and high risk of big debt if labor export fails.

\section{Box 3. Official capital source for labor export}

Every year, 10 to 15 households come to borrow capital to invest in labor export purposes. Their loan ranges from VND 20 million to VND 170 million. The Bank for Agriculture and Rural Development always has many packages to support labor export depending on the specific time and borrowers (mainly their economic condition). Basically, lending interest rates for labor export purposes are usually $2 \%$ to $3 \%$ lower than normal interest rates. Lending procedures are simplified, fast and convenient. Most people can pay off their debts after a year, but there are few cases where it takes many years for our bank to fully recover the debts.

Interviewing Ms. H - Branch Manager of Bank for Agriculture and Rural Development in Yen Khe commune

The costs for export labor and the incomes of migrant workers are significantly different in each country. These depend on many factors such as destination country, the time of labor export, brokerage cost in Vietnam, certain jobs and salary level. Table 3 illustrates the results of in-depth interviews on labor export costs to different markets in relation to income, remittances and payback period.

Table 3. Expenses for labor export and payback period

\begin{tabular}{|l|c|c|c|c|}
\hline Market/Country & $\begin{array}{c}\text { Average cost for } \\
\text { export labor } \\
\text { (million VND) }\end{array}$ & $\begin{array}{c}\text { Average } \\
\text { income/month } \\
\text { (million VND) }\end{array}$ & $\begin{array}{c}\text { Average monthly } \\
\text { remittance (million VND) }\end{array}$ & $\begin{array}{c}\text { Average payback } \\
\text { period (month) }\end{array}$ \\
\hline Japan & $150-200$ & $25-35$ & $17-20$ & $12-13$ \\
\hline Korea & $90-160$ & $25-30$ & $9-12$ & $12-13$ \\
\hline Taiwan & $100-120$ & $14-16$ & $6-8$ & $4-5$ \\
\hline Malaysia & $20-30$ & $10-12$ & & $7-8$ \\
\hline
\end{tabular}

Source: Fieldwork from November 2017 to November 2018 
The cost of labor export is often proportional to the income of the employee. High labor export costs mean high incomes, large remittances, and vice versa. As two countries with developed economies, Japan and South Korea require higher costs for labor export, but return higher income for workers. After deducting expenses for accommodation and living expenses, they can send back to their families from 15 to 20 million/month. This level of investment in labor export is suitable for families with good economy and can accept risks if labor export fails.

Taiwan is a new industrial territory, migrant workers in this labor market have to pay for labor export at average cost. In turn, they earn average income. The payback period is usually from 12-13 months. This market is suitable for households with average income, who have to borrow some part of the cost. Laborers working in Malaysia have to pay lower labor export costs and, in turn, earn the lowest income. Thus the payback time takes typically from 4 to 5 months. This market is suitable for low-income groups. The survey showed that out of 8 households with migrant workers in Malaysia , 2 households have enough capital to invest; 3 households have to borrow about $50 \%$ and 3 households have to borrow $100 \%$ capital. Although the income in Malaysia is not much higher than that in Vietnam, workers can solve the shortage of jobs and the current economic difficulties.

\section{Income from labor export}

Table 4 simulates the income of migrant workers in different markets after deducting investment costs. In cases with stable jobs, after the first 3 years of working overseas, labors in Japan and South Korea receive a relatively large amount of money, about VND 500 million. For the Japanese market, from 2017 onwards employees can receive a maximum of 3 years employment contract. Since 2018, thanks to the policies for the intern trainee program in Japan, Vietnamese export laborers in Japan are allowed to increase the contract term up to 5 years in all industries (Department of Labor - Invalids and Social Affairs of Thanh Ba District, 2018). For the Korean market, the first labor contract lasts up to 5 years, then depending on the partner, the contract may be extended for the second time from 3 to 5 years. Therefore, after 5 to 8 years of working in Korea, workers can earn from 1 to 1.5 billion. This is a very large amount compared to the unskilled workers working in Vietnam.

\section{Table 4. Income after 36 months of labor export}

\begin{tabular}{|l|c|c|c|}
\hline Market/Country & $\begin{array}{c}\text { Average cost for } \\
\text { export labor } \\
\text { (million VND) }\end{array}$ & $\begin{array}{c}\text { Average monthly } \\
\text { remittance } \\
\text { (million VND) }\end{array}$ & $\begin{array}{c}\text { Net income } \\
\text { after 36 months } \\
\text { (million VND) }\end{array}$ \\
\hline Japan & $150-200$ & $17-20$ & $460-520$ \\
\hline Korea & $90-160$ & $17-20$ & $520-560$ \\
\hline Taiwan & $100-120$ & $9-12$ & $220-310$ \\
\hline Malaysia & $25-30$ & $6-8$ & $190-250$ \\
\hline
\end{tabular}

Source: Fieldwork from November 2017 to November 2018

However, it is reported that there are many cases where workers are forced to return home before the contracts end. In these cases, the initial expenses have not been fully recovered. The reasons are varied from poor health condition, having an accident, unable to cope with the work pressure to other emergent problems during the first days working overseas. Returning home ahead of time causes significant economic losses for the workers and their families, it even takes many years to repay the borrowed capital/loan.

If labor export is successful, the economy of the whole household will be improved. The survey on 25 households with labor export shows in all three groups that their incomes increased significantly after having members working overseas with different income levels (Table 5).

Table 5. Income of households with export labor

\begin{tabular}{|l|c|c|c|c|}
\hline \multirow{2}{*}{ Group } & \multicolumn{2}{|c|}{$\begin{array}{c}\text { Income } \\
\text { Income/Difference }\end{array}$} & Ancome difference \\
\cline { 2 - 5 } & Before & 298.0 & 210.0 & 3.4 \\
\hline High income & 88.0 & 199.6 & 126.0 & 2.7 \\
\hline Middle income & 73.6 & 147.9 & 75.8 & 2.1 \\
\hline Low income & 72.1 & Million VND & Times \\
\hline
\end{tabular}

Source: Fieldwork from November 2017 to November 2018

Among households with export labor in Korea and Japan, the total income increases an average of 210 million/year, equivalent to 3.4 times for the high-income households. The middle-income households, the increase is respectively 126 million and 2.7 times. The group of low-income households, the increase is respectively 75.8 million and 2.1 times. The groups of middle- and low-income households usually have laborers working in Taiwan and Malaysia. Regardless of income groups, the income change proves that labor export has contributed significantly to the economic improvement of these households. 
Nguyen T.H. and Nguyen, T.T.T. / International Labor Migration: Employment, Costs and Income of Export Labors in Yen Khe Commune, Thanh Ba District, Phu Tho Province, Vietnam

Compared with the group of households without export labor, the income differences are more pronounced to all income groups but notably to the low income groups (see Table 6). The wider disparity among the low-income groups proves that labor export is of great significance, especially for the poor and near- poor households. However, this disparity also proves that the gap between rich and poor is widening in rural Yen Khe. Better-off households may continue to get richer while lowincome households have few opportunities to improve their income.

Table 6. Average income per capita per year of households in Yen Khe

\begin{tabular}{|l|c|c|c|c|}
\hline \multirow{2}{*}{ Income/Difference } & \multicolumn{2}{|c|}{$\begin{array}{c}\text { Average income per capita } \\
\text { (mil. VND) }\end{array}$} & \multicolumn{3}{c|}{ Income difference } \\
\cline { 2 - 5 } Group & $\begin{array}{c}\text { Households without } \\
\text { export labor }\end{array}$ & $\begin{array}{c}\text { Households with } \\
\text { export labor }\end{array}$ & mil. VND & Times \\
\hline High income & 41.3 & 71.7 & 30.7 & 1.7 \\
\hline Middle income & 23.6 & 52.9 & 29.3 & 2.2 \\
\hline Low income & 16.5 & 37.8 & 21.5 & 2.3 \\
\hline
\end{tabular}

Source: Fieldwork from November 2017 to November 2018

As can be seen in Figure 1 below, the income structure of the households with export labor has changed dramatically with the contribution of the income from export labor. The figure reflects the income structure of 25 households with export labor interviewed in Yen Khe. In particular, the proportion of

agriculture, manufacturing and some service sectors in the household income structure have dropped sharply as labor export accounts for $68 \%$ of household income. Laborers working overseas have become the key breadwinner, creating major part of their household income.

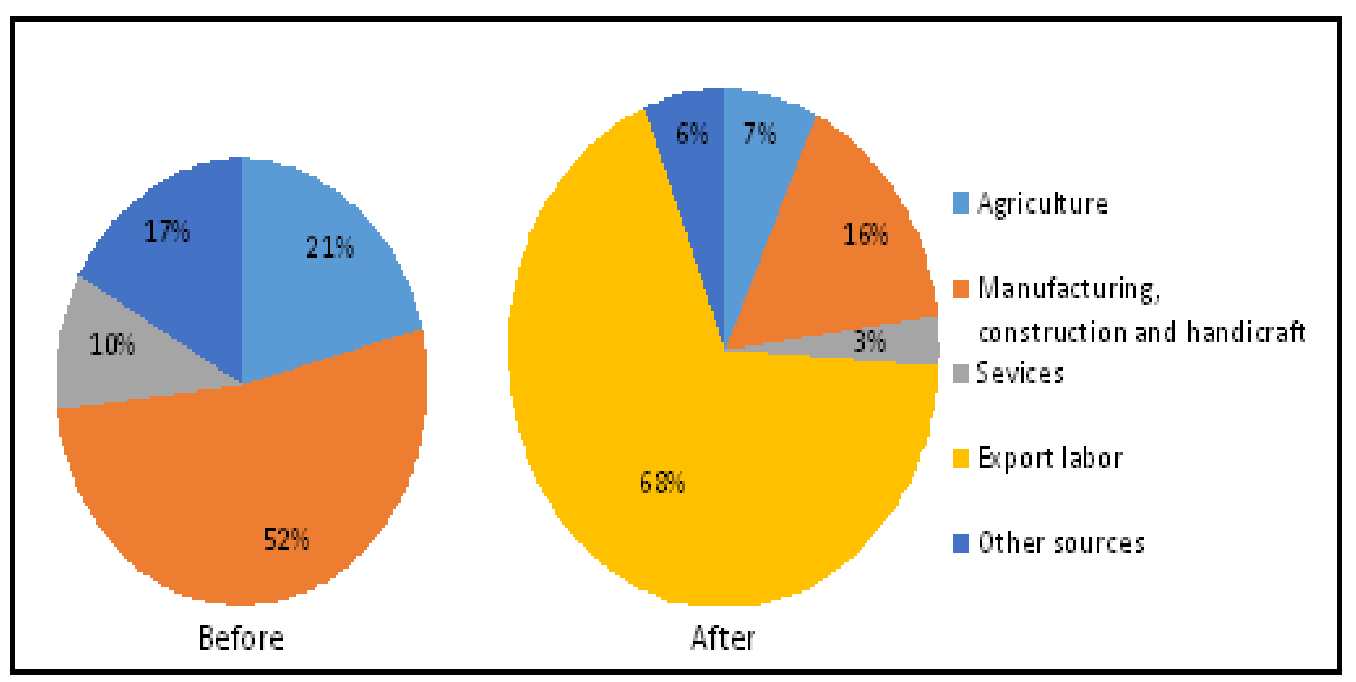

Figure 1. Income structure change of households with export labor

Source: Fieldwork from November 2017 to November 2018

However, research data also indicate that the remittances from labor export can be the cause of many negative social issues. Family members living at home are lazy and tend to rely on remittances from abroad. In other cases, many people easily

fall into gambling, alcohol, lottery, or prostitution. Besides, the increasing conflicts in families whose income has arisen so quickly in a short time is also the consequence of labor export.

\section{Box 3. Negative effects of the remittances on family members}

Ms. A, a neighbor of my family, has been working in Taiwan for 6 years. In the first two years she was able to send some money home to her husband. Her husband had money but got spoiled. We didn't see him doing anything, and not only that but drinking alcohol, gambling, and even having affair with another woman. Ms. A and her husband have only one son, who is now in grade 12 , but he followed his friends to play the lottery. Last time, Ms. A had to send ten millions to pay debt for her son. I heard that a few years later, Ms. A did not send money to her husband but sent it to her parents. It seems that her family doesn't know where to go.

Interviewing Ms. N, a neighbor of an export labor 
After 5 years of working as an export labor in Korea, I paid off the debt, bought some land and had a relatively large amount of money. All the money that I earned was sent home to my mother to keep. While waiting for the next 3year contract extension, I returned home and got married. When I returned to Korea to continue working, my wife and I wanted my mother to give me the money that I had accumulated during that period. However, my mother refused persistently because she felt no trust in my wife. My family have faced many conflicts as a result. I don't know whether to continue sending money to my mother or to my wife. If I have my mother's heart, I will lose my wife's and vice versa.

Interviewing Mr. T, an export labor in Korea

Another notable finding from our interviews with the participants is that some workers after returning home are lazy to work or cannot find suitable jobs, but rely on money earned from abroad for a long time. Of the 98 workers who have returned home, 10 are in voluntary unemployment. This can be explained by the fact that these workers have adapted to a decent work with high-income abroad and have not yet found suitable jobs in the country. Their life is still guaranteed by the money and interest from that they earned overseas. They are satisfied with that money, want to rest, and do not want to work immediately. Some laborers after returning from labor export are getting older, which makes it difficult for them to find suitable jobs to their age and health condition. This is a great waste of labor force and capital from labor export.

\section{Conclusions}

In the context of limitation of local livelihoods, labor migration in general and labor export in particular is a popular tendency selected by an increasing part of labor force in Yen Khe commune. Labor export not only helps to create jobs, reduce unemployment and underemployment, but also to diversify jobs for workers, contributing to economic restructure of the locality. Remittances from export labors contribute directly to the increase of individual workers and their families' incomes. Remittances have also transformed the income structure in the way that is less dependent on local livelihood capitals and local livelihood strategies.

However, labor export has also posed issues and consequences for individual export labors and their families. Notably, the status of illegal labor abroad, investment capital for labor export and related debts, services for labor export, voluntary unemployment, family conflicts, income disparities caused by remittances. These issues and consequences require appropriate solutions, especially labor training and labor export services, investment policies and capital support for labor export, development policies aim to mobilize and promote the values of employment, human resources and remittance from export labors.

\section{Acknowledgments}

This paper is based on the research approaches of the Ministrylevel Project "Migration and its impacts on livelihoods and poverty in coastal rural of the Red River Delta" (B2016-SPH02). The first author is the project leader. The second author is the first author's master student during the time of conducting her master thesis.

\section{References}

1. Anh, D. N. (2008). Labour migration from Viet Nam: issues of policy and practice. Bangkok, Thailand: ILO Regional Office for Asia and the Pacific.

2. Black, R., Bennett, S. R. G., Thomas, S. M., \& Beddington, J. R. (2011). Climate change: Migration as adaptation. Nature, 478(7370), 447-449.

3. Consular Department of the Vietnamese Foreign Ministry. (2011). Review of Vietnamese Migration Abroad. Retrieved 15 October, 2016, from http://www.un.org.vn/en/publications/doc_download/387review-of-vietnamese-migration-abroad.html.

4. Department of Labor - Invalids and Social Affairs of Thanh Ba District. (2018). Report on the results of the implementation of the employment program in Thanh $\mathrm{Ba}$ district from 2010 to 2018. Thanh Ba, Phu Tho.

5. Duyen, L. H. (2009). The impact of international labor movement on Vietnam's socio-economic development in international economic integration. Journal of Development Economics, 24(1+2), 13-19.

6. Ishizuka, F. (2013). International Labor Migration in Vietnam and the Impact of Receiving Countries' Policies. Retrieved 18 Octorber, 2018, from http://www.ide.go.jp/library/English/Publish/Download/D p/pdf/414.pdf

7. People's Committee of Yen Khe Commune. (2015). Socioeconomic development report of Yen Khe commune from 2010 to 2015. People's Committee of Yen Khe Commune.

8. People's Committee of Yen Khe Commune. (2017a). List of people going to work abroad in Yen Khe commune for the period of 2010 - 2017. People's Committee of Yen Khe Commune.

9. People's Committee of Yen Khe Commune. (2017b). Socio-economic development report of Yen Khe commune from 2015 to 2017. People's Committee of Yen Khe Commune.

10. Thanh Ba District Statistical Office. (2010 - 2017). Statistical Yearbook of Thanh Ba District from 2010 to 2017. Phu Tho: Thanh Ba District Statistical Office.

11. Vietnam Prime Minister. (2012). Decision No. 1201/QĐTTg Approving National target program on jobs and vocational training 2012 2015. Retrieved 20 June, 2018, from https://thuvienphapluat.vn/van-ban/Lao-dong-Tienluong/Decision-No-1201-QD-TTg-approving-National- 
Nguyen T.H. and Nguyen, T.T.T. / International Labor Migration: Employment, Costs and Income of Export Labors in Yen Khe Commune, Thanh Ba District, Phu Tho Province, Vietnam

target-program-on-jobs-and-vocational-training-2012-

2015-267757.aspx

12. Vietnam Prime Minister. (2017). Decision No. 899/QDTTg dated June 20th, 2017 of the Prime Minister on proving target program for vocational education, employment and occupational safety during 2016 - 2020. Retrieved 20 June, 2018, from https://thuvienphapluat.vn/ van-ban/lao-dong-tien-luong/quyet-dinh-899-qd-ttg-2017giao-duc-nghe-nghiep-viec-lam-an-toan-lao-dong352512.aspx 